\title{
Immigrant Students: The Attitudes and Perceptions of Teaching Staff
}

\section{Tommasa Agnese Chiofalo}

\author{
PhD, Teacher, \\ The Comprehensive Institute "Vittorino da Feltre," \\ Catania, Italy
}

\author{
María del Mar Fernández-Martínez \\ PhD, Professor \\ Department of Sociology, Social Work and Public Health, \\ University of Huelva, Spain \\ Corresponding Author
}

Carmen María Hernández Garre

PhD, Professor,

Departament of Education, University of Almería, Spain

\section{José Juan Carrión Martínez}

PhD, Professor, Coordinator of The Doctoral Program in Education, Departament of Education, University of Almería, Spain

Doi: $10.2478 / \mathrm{mjss}-2019-0061$

\begin{abstract}
Objective. In this article we discuss the attitudes of teachers towards immigrant students in the classroom and investigate the students' experiences and that of their family; the other important factor in their education. Method. The methodology used was qualitative interviews, carried out in a comprehensive school catering for the different stages of compulsory education in Sicily (Italy). In-depth interviews were performed on 15 teachers who tutored immigrant students, with the aim of revealing their thoughts, emotions, perceptions and attitudes with regard to this social and educational experience. Results. Although there were disparate elements within the context of the school, the results were consistent with other studies that address this global, contemporary problem. We found a pronounced receptivity on the half of the staff, good responses between equals, but also a degree of impotence and institutional neglect in the face of the problem. It was consistently perceived that families of immigrant students were rarely involved in school life. The influence of socio-economic, ethnic and religious factors that often affect relations between the immigrant student's family and the school, also emerged. Conclusions. The phenomenon of immigrant children's school integration is plagued with difficulties, which are repeated and maintained in different areas and periods of time. Within the school, the teachers take on the main task of offering these children a favourable environment for integration. However, the other major aspect of our study, the family relationship, was less encouraging. The teachers felt a lack of cooperation from the families of immigrant children.
\end{abstract}

Keywords: Immigration, Immigrant students, Integration; Teacher's attitudes, Family-school relations 


\section{Introduction}

Today's schools are significantly different to those of the past: the number of immigrant pupils has reached record highs (Berg \& Sigona, 2013; Blackledge, Creese \& Takhi, 2013; Bocagni, 2015; Meissner, 2015, 2016; Meissner \& Vertovec, 2015; Padilla, Azevedo, \& Olmos Alcaraz, 2015; Vertovec, 2007, 2010, 2013; Van Robaeys, Van Ewijk, \& Dierckx, 2018). This diversity affects all countries with an influx of immigrants.

The presence of immigrant students poses a dialectical problem for teachers who, on the one hand, try to treat them no differently than other students, as though there were no differences, and on the other, see those differences as an opportunity for cultural enrichment.

Teachers believe immigrant students do not become fully integrated until they have learned the language of their adoptive country (González Barea, 2008), and that their academic success is directly related to the degree of assimilation within the local culture (Etxeberria \& Elosegui, 2010). In a wider context, it is frequently seen that young foreigners are considered to be assimilated when they adapt to local habits and customs. In order to be fully accepted in the school environment, the young immigrant has to demonstrate his adaptation to the existing school behavioural model. If the foreigner shows some difficulty in adapting to the new system, students and teachers interpret this as a form of rejection towards those who wish to help him/her detach from their foreign characteristics, and is related to a lowering of expectations (Schachner, Juang, Moffitt, \& van de Vijver, 2018; Timmermans, Kuyper, \& Van der Werf, 2015; Van den Bergh, Denessen, Hornstra, Voeten, \& Holland, 2010)

According to Casalbore \& Fiorucci (2011), foreign students need a guiding figure, and frequently seek this in the school environment, where they often feel misunderstood. Giusti (2014) maintains that if they are properly guided, students learn to respect and value interculturalism. The immigrant student has to live with the two realities he is immersed in: school and family. These two aspects have different rules and principles that generate a degree of confusion and instability (González Barea, 2008).

The school cannot ignore or overlook the personal history of the immigrant student. The majority do not speak the local language and have to start from scratch to acquire new social and linguistic skills. This often presents difficulties in adaptation (Motti-Stefanidi, 2014), although Haenni Hoti, Heinzmann, Müller, \& Buholzer (2017) show this adaptation to be more balanced when acculturation elements are integrated with the preservation of the culture of origin (Mana, Orr, \& Mana, 2009; St-Hilaire, 2002).

\section{The Teacher's Role in a Changing School Environment}

There is no doubt that the teacher plays a crucial role in achieving positive educational results (Dabach, 2015; Ho, 2015). The tutor's motivation and abilities contribute towards the formation of a high-quality teaching environment based on efficiency and effectivity, although there may be exceptions (Barbieri, Cipollone, \& Sestito, 2009; Ho, 2015).

Today, the teaching profession has become a difficult and not always satisfying one (Yakhnich, 2015). The experience of dealing with immigrant students is often difficult; the teacher becomes a principle figure in the child's need to establish a relationship with the new environment, and communication is not always fluid ( Kumar, Karabenick, \& Burgoon, 2015; Peguero \& Bondy, 2011).

The idea that the presence of immigrant students causes difficult and complex changes in teaching methods is the result of the predominant idea in our social and political context; that immigration is a problem. Although this is also sometimes due to a monocultural education system (Kumar, Karabenick, \& Burgoon, 2015; Olmos Alcaraz, 2010; Peguero \& Bondy, 2011).

In this study we pose the question of whether teachers have attitudes that facilitate the integration of foreign students, just as Gonzalez \& Darling-Hammond (1997) questioned in the American context; Sinkkonen \& Kyttälä (2014) in Finland; Giusti (2014) in Italy, and as those who call for revisions in teaching in the face of immigration are calling for (Fernández-Larragueta, Fernández-Sierra, \& Rodorigo, 2017; López Martín, 2017). 


\section{Method}

We used a qualitative interview as indicated by Stake (2007) to directly explore the perceptions and thoughts of individuals faced with the phenomena of immigrant students (Flickr, 2004; Taylor \& Bogdan, 2010). In this case it was the teachers who expressed what they wanted, felt and what they liked about the presence of foreign students. This design for this research project is aimed at analysing the new experience within the school; that is, the increase in presence of immigrant students in the classroom. People became the object of study.

\subsection{Objectives}

Analyse the perceptions, attitudes and ideas of teachers towards immigrant students.

Understand how the impact of this is perceived on the school climate

\subsection{Suggested prior categories}

To assist information collection we identified a series of prior categories, as shown in Table 1.

Table 1. Teacher's perception, attitudes and type of relationship: prior categories

\begin{tabular}{|c|c|}
\hline \multicolumn{2}{|c|}{ 1.Types of attitudes towards immigrant students } \\
\hline 1.1 & Disposition and empathy \\
\hline 1.2 & Stereotypes and prejudices \\
\hline 1.3 & Feelings towards immigration \\
\hline $\begin{array}{l}\text { 2. } \mathrm{T} \\
2.1 . \\
2.2 .\end{array}$ & $\begin{array}{l}\text { er's attitudes towards the immigrant student's family } \\
\text { her/family relationship } \\
\text { encing elements }\end{array}$ \\
\hline
\end{tabular}

\subsection{Context and respondents}

The context of the study was a secondary school of education (Istituto Comprensivo) in the municipality of Partanna, Trapani province, Italy, which we shall not name for reasons of confidentiality. Partanna has experienced a marked increase in immigrant students in recent years. The school consists of five separate complexes, housing approximately 1,000 children of different educational levels: kindergarten, primary and lower secondary. Although the number fluctuates, at the time of the study there were 32 immigrant students of various origin: Eastern Europe, Northern Africa, Sub-Saharan Africa, the Middle East and the Caucasus.

The interviewees were 15 teachers (14 female and one male) belonging to two of the 5 complexes that make up the school, who were considered relevant respondents (Albert Gómez, 2009). The presence of immigrant students in the class was taken into account in the choice of these teachers, comprising students of primary school age, 6 to 10 years old who represented almost the totality of immigrant children present in the school. Table 2 shows the number of participants and their particular school complex.

Table 2. Respondents, codes and area

\begin{tabular}{cc}
\hline Interviewees (coded) & Area of work \\
\hline IDOC1prim & $\mathrm{A}$ \\
IDOC2prim & $\mathrm{A} / \mathrm{B}$ \\
IDOC3prim & $\mathrm{A}$ \\
IDOC4prim & $\mathrm{B}$ \\
IDOC5prim & $\mathrm{A}$ \\
IDOC6prim & $\mathrm{B}$ \\
IDOC7prim & $\mathrm{A}$ \\
IDOC8prim & $\mathrm{A}$
\end{tabular}




\begin{tabular}{cc}
\hline Interviewees (coded) & Area of work \\
\hline IDOC9prim & $\mathrm{B}$ \\
IDOC10prim & $\mathrm{A}$ \\
IDOC11prim & $\mathrm{A}$ \\
IDOC12prim & $\mathrm{A}$ \\
IDOC13prim & $\mathrm{A} / \mathrm{B}$ \\
IDOC14prim & $\mathrm{A} / \mathrm{B}$ \\
DOC15prim & $\mathrm{A}$ \\
\hline
\end{tabular}

\subsection{Technique for gathering data}

We used the qualitative interview technique on the 15 teachers mentioned, which best suited the objectives, aims and focus of the study. The aim was to provide researchers with the opportunity to gather a cross-referenced understanding of the phenomenon of immigrant students in class and the teacher's reactions. The interviews were carried out individually, respecting anonymity and the spontaneous willingness of each to participate, and always at the school premises.

\subsection{Research procedure}

Initially, we established contact with the school director, requesting permission to carry out the study, explaining our aims and the kind of research involved. We began by immersing ourselves in the environment for a week, in a 'wandering' style as described by Rodríguez Gómez, Gil Flores, \& García Jiménez (1999), in order to assist comprehension of what we were to hear and be better able to present the reality and carry out the interviews.

\subsection{Data analysis}

Table 3. Proposed final categories

\begin{tabular}{ll}
\hline Categories & Subcategories \\
Attitudes towards immigrant students & Empathy towards the immigrant student's situation \\
& Stereotypes and prejudices \\
& Teaching difficulties; the Italian language \\
& Lack of aid: lack of mediators, materials and training \\
\hline Attitudes towards the immigrant student's family & Low level of participation \\
& The socio-economic and cultural element \\
& The religious element \\
\hline
\end{tabular}

The interviews were recorded on a tablet and were transcribed into 15 text archives of data. These were analysed and categorised in the light of the prior categories, or new ones that emerged, the different segments were codified into the initial categories, or new ones. The texts were then divided into groups according to the final categories before completing our study. The proposed final categories were (Table 3).

\section{Results}

The data was interpreted with the aim of understanding to what degree these prior-categories were present in the teacher's perception of immigrant students. Said perceptions and feelings may influence the integration of these students into the school environment.

There was no doubt that the aspect of attitude was of great importance in determining and influencing teaching, in fact it was often the determining factor. The perception of the school context influenced the teacher's performance, which was based on the interpersonal relations established with their students. We shall illustrate these perceptions using the testimonies of these teachers. 


\subsection{Attitudes towards immigrant students}

\subsubsection{Sensitivity and empathy}

The school experience is one of relationships for both students and teachers, in which empathy becomes the fundamental aspect of the teacher's actions, since it is through empathy that teachers come to understand the student and his or her needs. The empathy component is essential in any pupil-teacher relationship but becomes even more important in relationships between tutors and immigrant pupils, who frequently experience difficulties and situations of need, precisely because of their immigrant status. This is confirmed by teacher IDOC1 prim:

The teacher's first approach, in general with any student, independent of their nationality, should be welcoming. From both the psychological and empathetic standpoint ... and then everything depends on that initial empathetic approach ${ }^{1}$ (IDOC1prim).

The teachers displayed empathy with the extreme situations these children had experienced at very early ages. In addition to language difficulties, which limited their ability to communicate with others, they had difficulties fitting in to completely new and unknown social and educational situations:

Of course, there is always a feeling of tenderness towards these children, emotions, understanding and empathy with their situation. (IDOC9prim).

Sometimes I can see uncertainty in the immigrant children's eyes, they feel lost and are looking for help, especially from the teacher who becomes an important figure, particularly in the sense of protection and guidance. (IDOC8prim).

The teacher understands the importance of encouraging and rewarding the student who is experiencing difficulties with an uncomfortable situation, separated from the reality which used to be his, just before he arrived in Italy. The school also has the opportunity to use the arrival of these immigrant children to draw attention to one of the most important social and civil attributes: that of respect for those who are different. This forms the foundation of a constructive debate as to what respect and civil behaviour mean, going into the concept of acceptance:

I have to evaluate that child, who is already insecure due to the situation he's in as a foreigner. I take inspiration from these situations to get the class to reflect on what it means to respect the other person, the rules and so on (IDOC8prim).

For the teachers, the presence of immigrant children in the classroom helps towards overcoming ethnocentrism, because often the Italian children are curious, and compare themselves to those who come from another culture. This comparison gives rise to new stimuli and a desire to know more. Among the respondents, a minority complained that the presence of immigrant children in the class slows down the rhythm of teaching because of the need to explain subjects:

So usually we have to slow down, teachers have to stop, which means the class does, and their energy goes to waste, because they're children and can get bored. So, you have to organise for both jobs in the classroom, and for homework, and that sometimes means the more able students lose interest (IDOC1prim).

Thankfully, the more positive views are in the majority:

I must say that families have welcomed this child in a positive way, so much so that they provide him with school material, the mother is expecting, and the father doesn't always have work, as far as I know. The other fathers also help with things like food, clothes. This little girl has been warmly welcomed, they even offer to take her home because the mother is pregnant and having some difficulties (IDOC9prim).

\footnotetext{
${ }^{1}$ Original testimonies translated from Italian by the authors.
} 
The words of teacher IDOC9prim, show us that the parents of Italian children are aware of the presence of these immigrant children in the country's social fabric, they show this sensitivity in the work and support they provide for the families of immigrant children, who have limited means:

I must say I am happy with the parents. They're making a collection for the crib for the baby, at Christmas they made a collection and then they take turns, especially these days while the mother is about to give birth, to take the little girl home. And they say: I've got her today, I'm taking her", so there's this collaboration and help (IDOC9prim).

It is certainly true, as this teacher's words show, that there is a positive and welcoming attitude from the families towards the newly arrived. A spirit of collaboration and participation that will form the basis of peaceful civil unity, almost establishing a kind of mutual aid in favour of those in need.

\subsubsection{Stereotypes and prejudices}

We have tried to establish whether the teachers perceived any stereotypes and/or prejudices concerning the immigrant children, and whether this eventually affected their work or the atmosphere in the classroom. Prejudices generally arise through ignorance or lack of trust in the person who is the object of that prejudice and discrimination, and who is perceived to be unassimilated.

Our evidence showed that stereotypes and hostile behaviour may manifest towards immigrant students, but in rare cases, as the teachers explained:

Sometimes there are a few stereotypical reactions, in the sense that Italian kids see the immigrant kids as ... er ... bad foreign kids (IDOC1prim).

The whole class welcomed him ... except one kid [...] who wasn't there when I introduced him (IDOC6prim).

Diversity in the school context generates fears and apprehensions among children, which require the teacher's intervention, to prevent them from becoming strongly stereotypical attitudes. Children have the right to ask questions, it is not easy for them to passively accept everything they're presented. Only through adequate explanations and convincing, clear answers do they learn to interiorise the rules of cohabitation. They are capable of taking a step back and making acceptance a totally natural occurrence:

[...] He didn't stop telling his mother: 'but his skin is black' (IDOC6prim).

From the beginning, this kid, [...] you could see the curiosity about his looks among the other kids, ... this interest in seeing a girl who was a different colour, had a different hairstyle, so there was almost this block, not just of classmates, but 10 minutes before class started there were children from other classes there, looking at this child. But after, not even a week, it became normal (IDOC9prim).

In the end, the class represents a real society, a reduced version of the reality that surrounds us. Just as sometimes it is hard to live in harmony in civil society, the same can be said of the classroom, where it becomes obligatory: a pupil is obliged to live with a classmate he may not like, he cannot avoid it. Children frequently lack the maturity to understand certain situations, in his imagination the immigrant classmate may also be a hostile figure to be avoided. This is why intervention by the teacher is necessary, and sometimes inevitable. The teacher must have the personal and professional capacity to make children understand how to communicate with each other, Italian or foreign, and that this is always a source of enrichment and comparison; things that contribute towards personal growth:

I think children don't see the differences between them, I mean they don't see it as differences on the cultural or family level. On the contrary, I must say that those who are having difficulty are helped by others, never marginalised, and this is positive (IDOC7prim).

It seems evident that our respondents agree that in the event of disagreeable episodes that 
isolate an immigrant child in the classroom, because they're victims of their classmate's wrong ideas or preconceptions, they don't hesitate to work against these attitudes by initiating a dialogue aimed at preventing the spread and persistence of such ideas and behaviour.

\subsubsection{Teaching difficulties: the Italian language}

The empathy that frequently motivates the teachers in their treatment of immigrant pupils, means that they are conscious of the difficulties these pupils face in comparison with their Italian counterparts, more so in the school context. These difficulties make their task as tutors much harder. All of the respondents in our research pointed out the language as the first obstacle, along with cultural factors that often conflict with those in the adopted country, and which may have repercussions on the learning process:

Language difficulties, as well as cultural, cultural in a certain sense, those related to customs (IDOC1prim).

The limiting factors are without doubt, the lack of knowledge of the language, that makes learning difficult, it makes learning the written language difficult and therefore, verbally (IDOC2prim).

Language proficiency is the basis of teaching and communicating. In school and all other areas of life, the means of communication is language, both written and verbal. If the means of communication is lost, then the pupil will not progress academically.

The immigrant child already has his own means of communication; his mother tongue, which he is still learning. He may not yet know how to write it fluently and correctly, but he certainly speaks it, with his family it is the language of feelings, of his country of origin. Italian is therefore his second language which he must learn through the teacher's techniques and these are different to those the teacher uses with the rest of the class:

I think language is a limiting factor for me (IDOC6prim).

[...] he must learn the classroom regulations without having been taught, he had to do everything this year, and follow classroom activities, but he carries on. He's helped by the teacher, one on one, closely, and also by the best classmates who have welcomed him really well (IDOC9prim).

I've always said that learning happens with affection. So, if you establish a positive empathetic relationship with the student, even if there's a language barrier, undoubtedly you have to work hard and you're never going to get the same results because if I have to do Italian ... I felt I had an advantage because I was doing maths, if the Italian teacher had to make up a sentence that the child couldn't understand, but affection eventually opens you to learning, I think (IDOC6prim).

\subsubsection{Lack of aid: no mediators, material resources or training}

The majority of teachers felt that a cultural mediator is required. Someone who would contribute towards learning beyond the language, encouraging integration and enabling the immigrant child to take advantage of the same resources as his classmates. Through one-on-one relationships the mediator would help the foreign child acquire the basics of the language which would open the doors to dialogue and a conscientious communication:

We don't have a cultural mediator which is essential for some students. In fact, for these Russian kids we had great difficulties in communication. I think in other schools, for example the prefecture of police is there ... more often. A cultural mediator in schools is essential, they even come close to a psychologist (IDOC2prim).

We don't have any supporting teachers or anybody to help us (IDOC5prim).

Language laboratories are also lacking, unfortunately due to a lack of economic resources, which largely affects all Italian schools. The courses in Italian language are also considered to be insufficient:

The course is aimed at children in second grade, and third and fourth year of primary school, who, although they live in Italy, they don't have enough language skills and only rudimentary Italian. 
They have serious difficulties and gaps in knowledge that undermines their active participation in class. This makes their progress and maturity very difficult (IDOC4prim).

This year they started a recovery course for immigrant children, 30 hours, but it wasn't very successful (IDOC4prim).

[...] 30 hours, and after 30 hours you can't tell who knows what. (IDOC5prim).

"30 hours, it's very little, these children who arrived at the start of the year didn't know Italian, so we had to do something urgently, that's why we did it, and all of those who needed to, participated. The little Rumanian girls participated, all of those who needed it (IDOC9prim).

Instigating a language project to assist in ordinary education was considered to be very important by all the teachers. But the number of hours dedicated to the language laboratory should be extended and should last throughout the entire school year. This would enable the pupils to acquire the basic language skills to manage the school year serenely. It would be of assistance to the teacher in their classwork.

\subsection{Immigrant family attitudes to the children's school life}

\subsubsection{Low level of participation}

Practically all of the respondents complained of the low level of parents' participation in school life. School and family are considered to be the main educational agents influencing the child's trajectory, their participation is considered indispensable in guaranteeing the best possible outcome. Foreign families often think that the school should find curricula measures to educate their children, as though this were not something that continued within the family environment, where what has been taught should be consolidated.

In immigrant families, the mother often plays a secondary role, particularly in Muslim families where patriarchy is established. This in turn results in an unstable communication for the school itself:

For example, one thing is the relationship with the female teacher, and another thing with the male teacher. I mean, the child himself sees more authority in the male figure than the female, and this is something that I always notice. Even in very small children, 7 or 8 years-old. Oh yes, I repeat; relations with the family are not easy (IDOC1prim).

By offering their opinions on the relations between teachers and fathers, the teachers define the fathers as a bit tired, due to the lack of language comprehension. These opinions are not universal, they don't apply to all immigrant families. Often the lack of interest shown by the families towards the school depends on the amount of time they have been in Italy, or even on the social class they belong to:

I need to have a relationship with the parents. Again, sometimes the parents of the foreign children seem not to trust the native parents. Maybe that's just their nature. Us teachers try to get to know the families gradually, we respect their ways, their habits (IDOC8prim).

The teachers would like the families to participate more in the lives of immigrant children, perhaps through intercultural projects that aim to involve them in real classes in which they can give their own account of their culture. This would encourage a comparison between the two cultures which would be the basis of a multi-ethnic school, giving rise to a communication with the families which is often missing:

I would like more collaboration from the families to get them involved, perhaps through projects designed to get to know the culture and traditions of different people and ethnic groups, but that ... I think ... is very hard to achieve (IDOC8prim).

\subsubsection{The socio-economic and cultural element}

The social class the immigrant child belongs to is one of the elements that may discourage them 
from fully experiencing school life. The family unit is where the child grows up and develops, inherits the culture, values and behaviour that undoubtedly influence his future educational and social development. Having a highly cultured family guarantees better opportunities, and related economic future:

[...] sometimes they can't provide the school kit2 ... these are poor families living with just a few cents, any extra spending, even on an exercise book etc, can mean a huge hole in the family budget (IDOC8prim).

When the family has economic difficulties, to the extent that they can't afford the school kit, they feel inadequate, this creates a distance between them and the school because they're afraid of being judged negatively.

Another aspect that often contributes to the gap between foreign families and the school, is cultural. The teachers try to recuperate the family's scarce involvement through cultural activities. But the kind of school these families have in mind is not the same; they delegate the educational expectations fully on the school. It is probably because of this that they have no interest in the child's school life, they are used to a different education system, with different regulations and where the parent's absence from school is normal:

I would say the relationship with the families is, how should I put it ... er, a timid one. Unfortunately, the lack of Italian is a powerful impediment. What do I mean by that? Well, when we need to tell the parents about something, they don't always understand us, and they don't always realise what their children are doing, unfortunately because of a lack of knowledge (IDOC11prim).

\subsubsection{The religious element}

Sometimes the type of relationship established between the immigrant families and the school is influenced by the family's religion, notably ethnic Arab Moslems. The teachers noticed a marked distancing of the Arab families, who were often rigid and rejected socialising due to religious reasons. They often displayed a lack of confidence in the school, which did not help to flexibilise communications:

These families are very tight knit because the Moslem religion is not open to debate, or to comparison [...] you don't see them much, they never ask how their children are doing, nothing. Only at the beginning, maybe to make sure the kid doesn't need anything, but after that, you don't see them. I must say, that with Moslem kids, maybe it's just me, maybe they come a few times to tell you the kid doesn't need to take religion, yes, at the most. But also considering other teachers, maybe because of religion, but then with other colleagues there's never, these ... these parents are not involved (IDOC13prim).

Some teachers said they had experienced very poor communication with families, especially with those of Moslem children which was almost non-existent. The main concern for these families was that their children should not attend religious classes or come into contact with foods their religion forbade them from eating. For everything else, they were unconcerned, showing a degree of disinterest in their child's schooling. When they did come to meetings, they displayed an imposing or critical attitude towards teaching methods, but did not participate in pedagogic dialogue, which the teachers would have greatly appreciated:

Sometimes they want to talk about teaching [...] but then they try to impose their views, not accept ours. Even though we talk about a legitimate and fair exchange, sometimes they try to impose on you, and that's not good, because the laws are there for everyone. So, what we do is grit our teeth, we can't ... we politely try to make them understand that the rules are for the whole class and should be respected (IDOC 13prim).

\footnotetext{
${ }^{2}$ Children are expected to have a school bag with notebooks, textbooks and stationary
} 


\section{Conclusions}

The phenomenon of immigrant children's school integration is plagued with difficulties, which are repeated and maintained in different areas and periods of time. Within the school, the teachers take on the main task of offering these children a favourable environment for integration. These teachers show a notable degree of empathy and sensitivity, just as Lääkkölä, Määttä, \& Uusiautti (2014) found in the highly regarded Finnish school system; Etxeberría \& Elosegui (2010) found in their study carried out in the Spanish Basque region, the area with the greatest degree of educational development, integration and resources in Spain; and shows great similitude to the results of Green, Perreira, \& Ko (2016). It is worth noting the similitude in the results of this study in Italy with those of such disparate and geographically distant places: Finland, the Basque region of Spain, and North Carolina, USA.

From the analysis of the different conclusions drawn from this study, it is possible to say that teachers use the presence of recently arrived immigrant children in the classroom to encourage the rest of the class to reflect on the themes of diversity, in its racial, cultural and gastronomic aspects, aiming to achieve a good atmosphere. This agrees with the conclusions of Schachner et al. (2018). There is a need for a reciprocal process that teachers do not perceive from the families, as González Barea (2008) also concluded. On the other hand, the immigrant child is totally involved, being the main character in the logical discussion of ideas and opinions, which benefits the whole class. The children gain useful and interesting knowledge about life-styles in other countries which would otherwise have been unknown. This is in contrast with the less homogeneous results on the existence of prejudices found by Van den Bergh et al. (2010).

Unlike the results obtained by Rodríguez Martínez (2009) which pointed towards a frequent rejection between equals, the teachers count on the collaborative attitudes of their local pupils, who welcome the newcomers. The immigrant children are welcomed no matter what their differences, the only thing that counts is that they are children like them; different in many ways, but children just the same. This aspect also corroborates the results of de Sanhueza Henríquez \& Cardona Moltó (2009).

The teachers perceived the greatest pedagogical difficulties were exacerbated significantly by language difficulties Cobo Ortiz (2008). In their opinion, this was directly attributable to the lack of material resources

The other major aspect of our study, the family relationship, was less encouraging. The teachers felt a lack of cooperation from the families of immigrant children. This agrees with recent studies by Pascale, Carrión Martínez, \& Fernández Martínez (2017), also in the Italian context. When the families do participate, it tends to be superficial in terms of interest in the child's performance and is directed simply at school materials. The teachers feel that the school does everything it can to involve the families of immigrant children in school life, but does not always reach its goals. The child is frequently the only link between the two institutions, as though he were the mediator between the two realities of which he is a part.

No prejudices are perceived either from the families or from the school, at least in general terms, but relations between the school and families is only possible when there is a similar, shared evaluation of the function and culture of education. This is not perceived by the majority of teachers with immigrant pupils, and they recognise the special influence that socio-economic standing, ethnic, cultural and religious elements have on this aspect.

When there are disagreements between the school's educational expectations and those of the family, then teaching becomes difficult. Misunderstandings are generated between the two worlds; family and school, whose task is to work together on the child's development.

As a final reflection, we could claim that there are common elements in our results and those of the different studies we have cited and used in comparison, that make up an almost universally problematic paradigm. The difficulties are not limited to immigrant children, as Rodríguez Izquierdo (2003) points out, but the protagonists perceive and feel they represent a singularly differentiated scenario, while political leaders feel involved only so far as formality and bureaucracy GómezHurtado, González-Falcón, \& Coronel (2018). Faced with the persistence and geopolitical universality of the results of various studies, the consistency in attitudes and perceptions of 
teachers that contrast again and again with certain theoretical guidelines on the subject from certain fundamental areas (mainly sociology, anthropology, and pedagogy), perhaps it is time to rethink the role of education for these children. Perhaps they need a more functional approach; one that pays more attention to what the teachers and parents have to say (which sometimes differs greatly from the theoretical analysis) since they are directly involved in the problem.

\section{References}

Albert Gómez, M.J. (2009). La investigación educativa: claves teóricas. Madrid: McGraw-Hill.

Aguado, T., Gil-Jaurena, I., \& Mata-Benito, P. (2008). El enfoque intercultural en la formación del profesorado: Dilemas y propuestas. Revista Complutense de Educación, 19 (2), 275-292.

Barbieri G., Cipollone P., \& Sestito P. (2008). Labour Market for teachers: demographic characteristics and allocative mechanisms. Giornale degli economisti e annali di economia, 66 (3), 335-373.

Berg, M.L., \& Sigona, N. (2013). Ethnography, diversity and urban space. Identities, 20(4), 347-360.

Blackledge, A., Creese, A., \& Takhi, J. K. (2013). Language, superdiversity and education. In I. de SaintGeorges y J.J. Weber (Eds.) Multilingualism and Multimodality (pp. 59-80). Rotterdam: SensePublishers.

Boccagni, P. (2015). (Super) diversity and the migration-social work nexus: a new lens on the field of access and inclusion? Ethnic and Racial Studies, 38(4), 608-620.

Casalbore, A. \& Fiorucci, M. (2011). Identità e appartenenze. Una ricerca tra i giovani con cittadinanza non italiana nelle scuole superiori di secondo grado a Roma. Pedagogia Oggi n. 1/2012 SIPED.

Cobo Ortiz, M. (2008). Inmigración en las aulas: percepciones prejuiciosas de los docentes. Papers: Revista de Sociología, 87, 253-268.

Dabach, D. B. (2015). My Student Was Apprehended by Immigration: A Civics Teacher's Breach of Silence in a Mixed-Citizenship Classroom. Harvard Educational Review, 85 (3), 383-412. DOI: 10.17763/00178055.85.3.383.

Etxeberría, F., \& Elosegui, K. (2010). Integración del Alumnado Inmigrante: Obstáculos y Propuestas. Revista Española de Educación Comparada, (16), 235-263.

Fernández-Larragueta, S., Fernández-Sierra, J., \& Rodorigo, M. (2017). Expectativas socioeducativas de alumnas inmigrantes: escuchando sus voces. Revista de Investigación Educativa, 35(2), 483-498 DOI: 10.6018/rie.35.2.257591.

Flickr, U. (2004). Introducción a la investigación cualitativa. Madrid: Morata.

Giusti, M. (2014). Immigrazione e consumi culturali: un'interpretazione pedagogica. Roma, IT: Gius. Laterza \& Figli Spa.

Gómez-Hurtado, I., González-Falcón, I., \& Coronel, J.M. (2018). Perceptions of secondary school principals on management of cultural diversity in Spain. The challenge of educational leadership. Educational Management Administration and Leadership, 46 (3), 441-456.

González, J. M., \& Darling-Hammond, L. (1997). New Concepts for New Challenges: Professional Development for Teachers of Immigrant Youth. New York, NY: Delta Systems Inc., McHenry, IL. Andrew W. Mellon Foundation.

González Barea, E. M. (2008). Convivencia intercultural en centros educativos multiculturales. ¿Hacia un reconocimiento de la diversidad cultural?. Educatio Siglo XXI, 26, 225-240.

Green, M., Perreira K.M., \& Ko L.K. (2016) Schooling Experience of Latino/A Immigrant Adolescents in North Carolina. In: Rong X.L., Hilburn J. (eds) Immigration and Education in North Carolina. Breakthroughs in the Sociology of Education (pp. 53-80). SensePublishers. Rotterdam: SensePublishers.

Haenni Hoti, A., Heinzmann, S., Müller, M., \& Buholzer, A. (2017). Psychosocial Adaptation and School Success of Italian, Portuguese and Albanian Students in Switzerland: Disentangling Migration Background, Acculturation and the School Context. Journal of International Migration and Integration, 18 (1), 85-106. DOI: 10.1007/s12134-015-0461-x.

Ho, S. H. (2015). TI Humanities studies of discourse of immigration shown in <Wandeugi>, Focusing on the Role and Significance of the Collaborative Teacher. The Journal of Korean Fiction Research, 59, 403-426.

Kumar, R., Karabenick, S. A., \& Burgoon, J. N. (2015). Teachers' implicit attitudes, explicit beliefs, and the mediating role of respect and cultural responsibility on mastery and performance-focused instructional practices. Journal of Educational Psychology, 107(2), 533-545. DOI:10.1037/a0037471.

Lääkkölä, R., Määttä, K., \& Uusiautti, S (2014). Teachers' Perceptions of Immigrant Students' Preparatory Teaching and Experiences of Cooperation in Basic Education in Finland. Advances in Psychology Study, 2 (1), 2-11. Retrieved from http://researchpub.org/journal/aps/archives.html.

López Martín, R. (2017). Hacia una pedagogía de la diversidad o la exigencia de repensar el carácter inclusivo de la escuela. Pedagogía y Saberes, 28, 31-42. 
Mana, A., Orr, E., \& Mana, Y. (2009). An integrated acculturation model of immigrants' social identity. Journal of Social Psychology, 149 (4), 450-473. DOI: 10.3200/SOCP.149.4.450-473.

Meissner, F. (2015). Migration in migration-related diversity? The nexus between superdiversity and migration studies. Ethnic and Racial Studies, 38(4), 556-567.

Meissner, F. (2016). Socialising with Diversity: Relational Diversity Through a Superdiversity Rotterdam: Springer.

Meissner, F., \& Vertovec, S. (2015). Comparing super-diversity. Ethnic and Racial Studies. 38 (4): $541-$ 555. DOI: 10.1080/01419870.2015.980295.

Motti-Stefanidi, F. (2014). Immigrant youth adaptation in the Greek school context: A risk and resilience developmental perspective. Child Development Perspectives, 8 (3), 180-185. DOI: 10.1111/cdep.12081.

Olmos Alcaraz, A. (2010). Construcción discursiva del alumno inmigrante extranjero en Andalucía: el otro en nuestras escuelas. Revista de Educación, 353, 469-493.

Padilla, B., Azevedo, J. \& Olmos-Alcaraz, A. (2015). Superdiversity and conviviality: exploring frameworks for doing ethnography in Southern European intercultural cities. Ethnic and racial studies, 38(4), 621-635.

Pascale, L. D., Carrión Martínez, J. J., \& Fernández Martínez, M.M. (2017). El estatus y roles de la familia en la escuela inclusiva en Italia: el caso de un instituto profesional. Revista de Educación Inclusiva, 10 (2), 181 194.

Peguero, A. A., \& Bondy, J.M. (2011). Immigration and Students' Relationship with Teachers. Education and Urban Society, 43 (2), 165-183. DOI: 10.1177/0013124510380233.

Rodríguez Gómez, G., Gil Flores, J., \& García Jiménez, E. (1999). Metodología de la investigación cualitativa. Málaga, España: Aljibe.

Rodríguez Izquierdo, R.M. (2010). Éxito académico de los estudiantes inmigrantes. Factores de riesgo y de protección. Educación XXI, 13 (1), 101-123.

Rodríguez Martínez, D. (2009). Chicos y chicas inmigrantes en el proceso de incorporación a un centro de secundaria. ¿Éxito o fracaso? Revista Iberoamericana de Educación, 49 (5), 1-15. Retrieved from https://rieoei.org/RIE/issue/view/183.

Sanhueza Henríquez, S., \& Cardona Moltó, M.C. (2009). Evaluación de la sensibilidad intercultural en alumnado de educación primaria escolarizado en aulas culturalmente diversas. Revista de Investigación Educativa, 27 (1), 247-262.

Schachner, M. K., Juang, L., Moffitt, U., \& van de Vijver, F. J. (2018). Schools as acculturative and developmental contexts for youth of immigrant and refugee background. European Psychologist 23 (1), 44-56. DOI: 10.1027/1016-9040/a000312.

Sinkkonen, H. M., \& Kyttälä, M. (2014). Experiences of Finnish teachers working with immigrant students. European Journal of Special Needs Education, 29(2), 167183., DOI: $10.1080 / 08856257.2014 .891719$.

Stake, R. (2007). Investigación en estudio de caso. Madrid: Morata.

St-Hilaire, A. (2002). The social adaptation of children of Mexican immigrants: Educational aspirations beyond junior high school. Social Science Quarterly, 83 (4), 1026-1043. DOI: 10.1111/1540-6237.00131.

Timmermans, A. C., Kuyper, H., \& Werf, G. (2015). Accurate, inaccurate, or biased teacher expectations: Do Dutch teachers differ in their expectations at the end of primary education? British Journal of Educational Psychology, 85(4), 459-478.

Taylor, S.J., \& Bogdan, R. (2010). Introducción a los métodos cualitativos de investigación. Barcelona: Paidós.

Van den Bergh, L., Denessen, E., Hornstra, L., Voeten, M., \& Holland, R. W. (2010). The implicit prejudiced attitudes of teachers: Relations to teacher expectations and the ethnic achievement gap. American Educational Research Journal, 47(2), 497-527.

Van Robaeys, B., van Ewijk, H., Dierckx, D. (2018). The challenge of superdiversity for the identity of the social work profession: Experiences of social workers in 'De Sloep' in Ghent, Belgium. International Social Work, 61 (2), 274-288.

Vertovec, S. (2007). Super-diversity and its implications. Ethnic and Racial Studies. 30 (6), 10241054. DOI:10.1080/01419870701599465.

Vertovec, S. (2010). Towards post-multiculturalism? Changing communities, conditions and contexts of diversity. International social science journal, 61(199), 83-95.

Vertovec, S. (2013). Anthropology of migration and Multiculturalism: new directions. London: Routledge.

Yakhnich, L. (2015). Immigrant Parents in the Educational System: The Case of Former Soviet Union Immigrants in Israel. Journal of Cross-Cultural Psychology, 46 (3), 387-405. 